\title{
Epididimis: van hoofspeler tot bysaak?
}

\author{
M.H. Fouric* en M.S. Bornman \\ Sentrum vir Fertiliteitstudies, Departement Urologic, Universiteit van Pretoria, Privaat sak X169, Pretoria, 0001
}

J.M.C. Oosthuizen

Departement Genceskundige Fisiologic, Universiteit van dic Oranje-Vrystaat, Posbus 339, Bloemfontein, 9300

Ontrang 8Augustus 1996; aantaar I November 1996

\section{UITTREKSEL}

Tydens hulle gang deur die epididimis verwerf sperme die vermö̈ om voon te beweeg en te bevrug. Funksioneel en meganies is die epididimis onmisbat vir in vivo-bevagting, maar wat betref in vitro-bevrugting het die tegnologie met rasse skrede vooruitgegan. Moderne sperminspuitingstegnieke het die epididimis 'n "bysaak" gemaak by die behandeling van individuele infertiele paartjies.

Wanneer die fertiliteitstatus van die globale bevolking ter sprake kom, speel die epididimis nog onteenseg/ik 'n "hoofrol". Dit sou belangrik wees om te bepaal of tanende testisftuksie, soos weerspieêl in wêreldwye dalings in spermtellings, gepaardgaan met dalende epididimisfunksie, wat sal lei tot afnames in spermflunksie. Epididimisfunksie kan bepaal word deur die bepaling van epididimale merkers, waarvan $\alpha$-glukosidase-aktiwiteit die effektiefste is. Ten opsigte van die klassifikasie van epididimale deurganklikheid het $\alpha$ glukosidase 'n suksessyfer van 88\% wanneer die afsnypant van 26,7 mU/ejakulaat gebruik word. Die EpiScreen $(R)$ kitsmetode vir $\alpha$ glukosidase-aktiwiteitsbepaling is geskik vir gebruik in die roetine diagnostiese laboratorium, maar vir navorsingsdoeleindes is die epididimisspesifieke metode verkieslik. 'n Enkele bepaling van $\alpha$-glukosidase vir diagnostiese doeleindes is voldoende, mits dit in samehang met die kliniese data gë̈nterpreteer word.

Ten opsigte van epididimale funksie toon $\alpha$-gltkosidase-aktiwiteit betekenisvolle positiewe korrelasies met spermmotiliteit en hegting aan die oösiet, maar is negatief gekorreleer met die teenwoordigheid van epididmispatologie. Hierdie korrelasies beklemtoon dat, hoewel moderne tegnologie wel die epididimis van die "verhoog" van in vitro-bevrugting mag stoot, die epididimis 'n onaanvegbare "hoofspeler" bly wanneer die gesondheid val die globale populasie ter sprake kom.

\section{SLEUTELWOORDE: EPIDIDIMIS, EPIDIDIMALE MERKERS, MANLIKE INFERTILITEIT, SPERMMOTILITEIT, $\alpha$ -} GLUKOSIDASE.

\section{Abstract}

\section{Epididymis: from lead player to side issue?}

During epididymal transit, sperm acquire the capacity for fertilization and progressive motility. The epididymis is functionally and mechanically indispensable for in vivo fertilization, but technology has progressed rapidly in the field of in vitro fertilization. Modern sperm-injection techniques have dispensed with the epididymis as a necessity in the treatment of individual infertile couples.

However, when the fertility status of the entire population is considered, the leading role of the epididymis still cannot be ignored. It is potentially important to determine if decreased function of the testis, as reflected in world wide reports of decreasing sperm numbers, is accompanied by decreasing epididymal function, which would result in decreasing sperm function. Epididymal function can be determined by epididymal markers, of which $\alpha$-g/ucosidase activity is most effective. The success rate of $\alpha-g$ lucosidase for the classification of epididymal patency is $88 \%$, using the cut-off point of 26,7 mU/ejaculate. The EpiScreen $(R)$ kit is suitable for routine diagnostic laboratory use but the epididymal specific method for research parposes. One determination of $\alpha-g / u c o s i d a s e$ for diag. nostic parposes is sufficient, providing that it is interpreted taking clinical data into account.

In relation to epididymal function, $\alpha$-glacosidase activity showed significant positive correlation with sperm motility and binding of the oocyte, but correlated negatively with the presence of epididymal pathology. These correlations emphasize that, though modern technology might have minimised the importance of the epididymis for in vitro conception, when the global health of the population is considered, the epididymis will maintain its leading role.

\section{INLEIDING}

Histories is die funksionele rol van die epididimis in die rypwording van sperme en die bewaring van volwasse sperme as onaanvegbaar beskou vir die produksic van sperme met die nodige bevrugtingspotensiaal. ${ }^{1-4}$ Die teenwoordigheid van deurganklike buise was ook 'n voorvereiste vir bevrugting by geassisteerde reproduksietegnicke. Hicrdie status van die epididimis is die afgelope tyd uit talle oorde bevraagteken, in so 'n mate dat dit wil voorkom asof hierdie hoof'speler in die drama van menslike reproduksie die gevaar loop om totaal van die verhoog te verdwyn en 'n blote bysaak te word.

Ten ecrste was daar sterk aanduidings dat dic epididimis, as gevolg van die kledingspraktyke van die moderne mens, nie sy natuurlike rol as veilige bewaringsruimte kan vervul nie. Die dra van relatief stywe en digte bedekkings, soos moderne mansdrag, lei tot 'n substansiële verhoging in die oppervlaktemperatuur van die skrotum en gevolglik die omgewingstemperatuur van die epididimis. Dit veroorsaak waarskynlik 'n direkte verlaging in die bewaringskapasiteit van die epididimis, met die gevolglike produksic van ejakulate van relatief minderwaardige kwaliteit. ${ }^{5}$ 
Ten tweede het onlangse, suksesvolle ontwikkelinge op die gebied van geassisteerde reproduksielegnicke, soos epididimalet en testikulêre ${ }^{7}$ spermaspirasies oënskynlik korte mette gemaak met die belang van die epididimis as meganiese buis en fisiologies-voedende en -beskermende ruimte waarbinne die onrype sperm maturiteit kan bereik. Hierdie lwee legnicke maak gebruik van onrype sperme wat direk uit die genoemde organe onturek word, om die oösiet te bevrug en skakel dus deurgang deur dic epididimis gedeeltelik of ten volle uit. Die doelwit van hierdic oorsig is die toeligting van die rol van die epididimis in manlike fertiliteit en die relevansie daarvan vir hedendaagse reproduktiewe navorsing, met spesiale verwysing na die kliniese belang van $\alpha$-glukosidase, wat tans die epididimale merker van keuse is.

\section{ANATOMIE VAN DIE EPIDIDIMIS}

Die epididimis is ' $n$ hoogs gekrulde buis van ongeveer 6 meter wat die rete testis met die vas deferens verbind' (liguur 1). Die gekrulde buis is op homself teruggevou en die hele struktuur is omsluit deur die bindweelsel van die tunica vaginalis, wat ook die testis omhul. ${ }^{8}$ Anatomies mag dit voorkom asof die epididimis bloot as verbindingsbuis funksioneer, maar dit is van kriticke belang vir dic post-testikulêre ontwikkeling van die sperm se bevrugtingsvermoë.

Die epididimis word in drie segmente onderverdeel, wat aan die buitckant van dic orgaan anatomies onderskei kan word $\mathrm{en}$ aan die binnekant van die buis op grond van histologiese eienskappe herkenbaar is. ${ }^{4}$ Proksimaal vanaf die test is is hierdie drie dele die caput, corpus en cauda epididimis (liguur I).

Voorheen was die ductuli efferentes apart van die epididimis beskou, maar in die mees resente literatuur word dit wel as deel van die menslike caput epididimis beskryf. ${ }^{2,3}$ Spermkonsentrasies in die testis is laag, maar verhoog relaticf oor die lengte van die epididimis as gevolg van vlocistolabsorbsic in veral die ductuli efferentes en die inisiële segment van die caput epididimis. ${ }^{2}$

\section{EPIDIDIMIS EN RYPWORDING VAN SPERME}

Die veranderende omgewing binne die epididimis. Veranderinge in die samestelling van die buisvog van die epididimis is in verskeic dieremodelle en spesifiek die rot $^{2}$ beskryl ten opsigte van dic $\mathrm{pH}$, ioonkonsentrasies en verskeic organiese komponente, waaronder die samestelling van proteiene. Veranderinge in die samestelling van die luminale vog van die epididimis is hoolsaaklik aan vier laktore te danke, naamlik dic resorpsic van water, dic sekresic en absorpsic van opgeloste slowwe (organies en anorganies) deur die epididimale epiteel en die metabolisme van sperme."

Die sekresic van 'n opgeloste stof mag plaasvind deur direkte oordrag vanuil die bloedstroom, soos die geval is met Lkarnitien, of via sintese deur die epididimale epiteel vanaf' $n$ voorloper uit die bloedtoevoer, soos die sintese van proteiene vanaf aminosure." Die sintese en sekresie van hierdie proteiene is gebiedspesifiek, sodat sperme tydens hulle deurtog deur die epididimis voortdurend aan 'n veranderende, unieke omgewing blootgestel word. Sommige van hierdie proteiene word aan die plasmamembraan van die sperme gebind en daarin geinkorporecr. $^{2}$

Genetiese studies het getoon dat die spesifisiteit van proteiensintese en -sekresie teweeggebring word deur die spesifieke ekspressie van gene in spesifieke areas van die epididimis. Hierdic gebiedspesifieke ekspressie word teweeggebring deur differensiële geenregulering deur androgene en/of testikulêre faklore." Die rol van die veranderinge in die mikro-omgewing wat die rypwordende sperme omring, word nog nie in detail verstaan nie, maar dit word algemeen aanvaar dat alwykings in die samestelling van die epididimale vog 'n negatiewe effek op die rypwordingsproses van sperme kan hê, met ongewenste gevolge vir manlike fertiliteit. ${ }^{2}$

Vir die daarstelling van die biochemies-gespesialisecrde omgewing waarin die sperm hom voortdurend bevind, is dic sogenaamde bloed-epididimisskans van kardinale belang. Hierdie skans word gevorm deur die digte aansluitings tussen die epiteclselle van die epididimis, " wat veroorsaak dat groot molekule nie vryelik tussen die bloedstroom en die epididimale lumen kan diffundeer nie. Hierdie skans stel die epididimis in staat om die in- en uitbeweeg van verskeic substanse te beheer, terwyl dit ook die sperme beskerm teen potensiecl skadelike invloede, soos toksiese melaboliete en omgewingsfaktore en ook teen die liggaam se immunsistecm. ${ }^{12}$

Vir al die bogenoemde funksies en vir die hooffunksie van spermrypwording is die epididimis athanklik van voldoende testosteroonvoorsiening vanaf die testis. ${ }^{13}$

Spermrypwording: motiliteit en bevrugtingspotensiaal. Dic doel van spermrypwording in die epididimis is tweeledig. naamlik die ontwikkeling van die vermoëns tot voorwaartse beweging en tot bevrugting van 'n oösiet. ${ }^{1,4,14}$ Grootskaalse biochemiese veranderinge van die sperm tydens epididimale deurgang en dic gepaardgaande rypwordingsproses is reeds beskryf, waaronder veranderinge aan die spermmembraan en ook sekere metabolicse veranderinge, ${ }^{2,4}$ wat van kardinale belang is om die doel van spermrypwording te bereik.

Ontwikkeling van spermmotiliteit.

Sperme vrygestel uit dic caput epididimis is immoticl of hul sterte toon slegs breë, stadige sweepslac, in tecnstelling met dic smal, vinnige sweepslae van volwasse sperme, wat eers waargeneem word by sommige van die sperme wat uit die middelste gebied van die corpus vrygestel word. ${ }^{5}$ Hierdie tipe motiliteit oorheers in die populasic wat uil die cauda vrygestcl word, dog hier
FIGUUR 1: Skematiese voorstelling van die testis, epididimis en die verskillende segmente van die epididimis. 
kan steeds 'n onverwagte hoé fraksie onbeweeglike sperme voorkom..$^{15}$

Die ontwikkelende vermoë vir funksionele motiliteit is mel groot akkuraatheid in opeenvolgende segmente van die menslike cpididimis aangetoon deur van rekenaar-geassistecrde spermanalise gebruik te maak. Hierdie studies toon dal die persentasie moticle sperme 'n piek bereik in die laer dele van die corpus, maar daarna weer afneem in die cauda. Die daling kan te wyte wees aan dic moontlike lang onthoudingsperiode by die groep van pasiënte met prostaatkarsinoom waarin hierdic studie uitgevoer is. ${ }^{13}$

Ontwikkeling van fertilisasiepotensiaal. Studies het getoon dat die vermoë van menslike sperme om zonavrye hamster-oösiete te penetreer en om aan menslike oösiete te bind, toeneem met die beweging van die sperme deur die corpus en cauda epididimis, ${ }^{4.14}$ Ander studies, veral dié van Schoysman ${ }^{16}$ en Silber, ${ }^{17}$ plaas 'n vraagteken oor dic noodsaaklikheid van blootstelling van rypwordende sperme aan die distale streke van die epididimis. In hierdie studies is in vitro-bevrugting en swangerskappe verkry by pasiënte met obstruksies in die epididimis ná hegting van die deurganklike deel van die epididimis aan die ductuli efferentes, ${ }^{7,17}$ Die suksessyfers was egter wel hoër indien die sperme deur 'n langer deel van die epididimis beweeg het. . $^{717.18}$

Hierdic oënskynlik tecnstrydige resultate kan verklaar word deur die moontlikheid dat obstruksic van die geslagsbuise in die mens 'n verskuiwing van die normale patroon en plek van spermrypwording in die epididimis kan veroorsaak en dat selfs die vas deferens en vasa efferentia hierdie funksies van die epididimis minstens gedecltelik kan oorneem.' In hierdie verband is getoon dat onomkeerbare veranderinge in dic epididimis ná die ontstaan van 'n obstruksie plaasvind, wat dit nog meer problematics maak om resultate van so 'n abnormale situasic na die normale fisiologiese toestand te ekstrapolecr. ${ }^{4}$

\section{VERVOER EN BEWARING VAN SPERME IN DIE EPIDIDIMIS}

Buiten die rypwording van sperme is die ander belangrike funksies van die epididimis die vervoer van sperme vanaf die testis na die gebied waar sperme funksioneel bewaar word totdat ejakulasie plaasvind. Die tyd wat dit sperme neem om deur die totale lengte van die epididimis te beweeg, is afhanklik van dic daaglikse produksietempo van sperme, sodat 'n relaticf vinnige deurgang van 2 tot 4 dae in baie gevalle algemeen is. ${ }^{45}$ Voorts is ook gevind dat kort tussenposes tussen ejakulasies die tempo van beweging deur die cauda epididimis kan verkort, maar geen invloed het op beweging deur die caput en corpus epididimides nie. ${ }^{4}$ Ná migrasie deur die caput en corpus is sperme in staat tot voorwaartse progressie en die fertilisasic van oösicte en word hulle in dic cauda bewaar. ${ }^{4}$ In teenstelling met die meeste ander soogdiere is die cauda epididimis van die mens swak ontwikkel en blykbaar nie geskik vir die langtermynpreservering van sperme nic. ${ }^{19}$ Een van die redes wat hiervoor voorgestel word, is dat 'n verhoging in die temperatuur van die skrotum (waarskynlik veroorsaak deur hedendaagse kleredrag) verskeic aspekte van epididimale funksic benadeel. ${ }^{5}$ Die funksies wat veral ter sprake is, is dié van die verskansing van spermkwaliteit in die cauda epididimis, wat die kwalitcit van die ejakulaat direk kan bcinvloed.

\section{DIE EPIDIDIMIS EN FERTILITEIT}

Dit is duidelik dat deurganklikheid en normale funksie van die epididimis van kliniese belang in fertiliteit is. Die insidensie van infertiliteit as gevolg van epididimes wat abnormaal of hoegenaamd nie funksioneer nie is steeds onbekend, dog epididimale obstruksie is die algemeenste oorsalak van asoöspermie (afwesigheid van sperme in die ejakulaat). ${ }^{20}$ Daar word beraam dat 'n manlike faktor by $50 \%$ van inferticle paartjies die oorsaak van primêre infertiliteit is, terwyl asoöspermic slegs by 3 tot $18,4 \%$ van hicrdic pasiënte voorkom. ${ }^{\mathrm{k} 21-23}$

Asoöspermic word, algemeen gesproke, veroorsaak deur meganiese obstruksies in die geleidingsbuise vanaf die testis, of deur totale alwesigheid van spermatogenese. Drie biochemiese komponente van die seminale plasma, wat almal deur die epididimis gesekreteer word, is voorgestel as epididimale merkers vir die differensiële diagnose van asoöspermic. Hierdic drie is die $\alpha$-glukosidase-ensiem, gliserolosfocholien en Lkarnitien (wat almal drastiese dalings in die ejakulaat ná vasektomie vertoon). ${ }^{13.1 \times}$

\section{$\alpha$-(ILUKOSIDASE-AKTIWITEIT: EPIDIDIMALE MERKER VAN KEUSE}

In studies waarin die drie vermelde merkers met mekaar vergelyk is, het $\alpha$-glukosidase-aktiwiteit na vore gekom as die merker van keuse vir onderskeiding tussen deurganklike en obstrukliewe epididimale buise. ${ }^{13,24}$ Met gebruik van die epididimisspesifieke metode is gevind dat $88,4 \%$ van gevalle korrek geklassifiseer kon word (afsnypunt van 26,7 milli-eenhede (mE)/cjakulaat). ${ }^{25,26}$ Waardes minder as $26,7 \mathrm{mE} / \mathrm{cjakulaat}$ dui met $\pm 90 \%$ sekerheid op die teenwoordigheid van 'n epididimale blokkasie. ${ }^{26}$ Een cenheid alfa-glukosidase-aktiwiteit is gelykstaande aan dic produksie van $1 \mu \mathrm{mol}$ van die produk van ensiemakliwitcil per minuut by $37^{\circ} \mathrm{C} .{ }^{29}$ Aktiwiteil word uitgedruk per ejakulaat en nie per milliliter $(\mathrm{ml})$ nic, omdat inter- en intra-individuele variasies in die bydrae van aanvullende geslagsorgane tot die cjakulaat voorkom en die proporsionele bydrae wat die epididimis tot die ejakulaat lewer nie konstant is nie. Om die onbekende verdunningsfaktor uit te skakel, word die totale produksic van $\alpha$-glukosidase-aktiwitcit dus gemeet. ${ }^{25}$

'n Nuwe ontwikkeling op die gebied van $\alpha$-glukosidaseakliwiteitsbepaling, wat veral dic aandag van roctinelaboratoriums sou trek, was dic ontwikkeling van die EpiScreen (R) kitsmetode (FertiPro N.V., Sint-Martens-Latem, België). Hierdie metode bespaar aansienlike voorbereidingstyd en is vir die doel van roetine diagnostiese bepalings gerieflik en tyd-en kostedoeltreffend. Die kitsmetode se sensitiwiteit is egter laag vir baic lac konsentrasies $(<2 \mathrm{mU} / \mathrm{mL})$. Hierdie konsentrasies lê egter ver onder die afsnypunt en het dus slegs vir navorsingsdocleindes implikasies. Wanneer veranderinge in epididimale funksic bepaal word, sal die epididimisspesificke metode van meer nut wees om dic verwagte subticle veranderinge in $\alpha$ glukosidase-aktiwiteit uit te wys.

Dit is by die interpretering van die merker uiters belangrik om daarop te let dat lac $\alpha$-glukosidase-aktiwiteit allecen betekenisvol is indien die hormoonprolicl van die pasient normaal is en volledige monsters spesilick ná dric dac onthouding van gemeenskap versamel is. Die kriticke belang van die hormoonproficl is toe te skryf aan die androgeenafhanklikheid van epididimale funksie. Lae vlakke van testosteroon sal epididimale funksie benadecl, met 'n gepaardgaande verlaging in die $\alpha$ glukosidase-aktiwiteit in die seminale plasma.

$\alpha$-glukosidase-aktiwiteit en spermmotiliteit. $\alpha$-glukosidase kom nie in sperme voor nie en die rol daarvan in die epididimis is waarskynlik om glukose te voorsien wat as energicbron deur dic sperme benut word, veral vir spermmotiliteit. ${ }^{27.2 x}$ In die rotmodel speel die ensiem 'n rol in die biochemiese instandhouding van sperme tydens hulle verposing in die cauda epididimis, waartydens 
die potensialal tot voorwatrtse progressie gepreservec moet word tot ejakulasie plaasvind. Teenstrydige resultate oor die verband lussen $\alpha$-glukosidase en spermmotiliteit kom in die literatuur voor. Sommige studies kon geen verband aantoon nie terwyl 'n positiewe verband wel in ander gevind is. ${ }^{13,30.32}$ In 'n onlangse studie is hoë $\alpha$-glukosidase-akliwiteit positicf gekorreleer met hoë persentasies sperme met gocie progressiewe spermbeweeglikheid. ${ }^{33}$ Dit stem ooreen met die voorkoms van goeic progressiewe spermmotiliteit by ferticle mans. ${ }^{34}$

Dic afsnypunt vir gocic spermmotiliteit $(26,8 \mathrm{mE} \alpha-$ glukosidasc-aktiwitcit/cjakulaat) was byna identies aan die afsnypunt vir deurganklike epididimale buise $(26.7 \mathrm{mE} /$ ejakulaat). ${ }^{33}$ Die klassifisering van goeie en swak spermbeweeglikheid ewenaar egter nie die ensiem se akkuratheid as merker van epididimale deurganklikheid nic. Dit beklemtoon ten eerste dat $\alpha$-glukosidase-akliwiteil malar een van verskeic laktore is wat spermmotiliteit beïnvloed en ten tweede dat $\alpha$-glukosidaseakliwiteit ' $n$ aanduiding van epididimale funksie per se is. Hierdie verband is ook alangedui in pasiente met inleksie van die epididimis, wat presenteer het met lac waardes van $\alpha$-glukosidase-aktiwiteit. ${ }^{36.25}$

$\alpha$-glukosidase-aktiwiteit en bevrugting. ' $n$ Verband tussen $\alpha$ glukosidase-aktiwiteit en bevrugting is onlangs geimplisecr deur die positiewe korrelasie tussen $\alpha$-glukosidase-aktiwiteit en spermbinding aan die zona pellucida van dic oösiet, wat die eerste stap in die bevrugtingsproses verteenwoordig. ${ }^{36}$ In 'n poging om 'n in vivo-afsnypunt vir "normale" $\alpha$-glukosidaseaktiwiteit te bepaal, is die seminale akliwiteit in 'n groep van bewese ferticle vaders bepaal. Die reikwydte van aktiwiteit wat in hierdic groep mans gemeet is, was baie wyd $(5,1$ tot $204 \mathrm{mE} /$ ejakulaat) (mel waardes beide onder en bo die afsnypunt van $26,7 \mathrm{mE} / \mathrm{ejakulaal).}{ }^{33} \mathrm{Vyl}$ persent van die bewysde vaders het $\alpha$-glukosidase-aktiwiteit van $5,1 \mathrm{mE} / \mathrm{cjakula}$ at gehad (dic sogenaamde 5 de persentiel). Die 5 de persenticl geld dikwels as 'n alsnypunt, maar was in hierdie geval onbruikbaar laag. ${ }^{3 .}$

Bovermelde beklemtoon die risiko daaraan verbonde om op 'n enkele parameter statat te mak om die lertiliteitstatus van 'n pasiënt te beoordecl. Soos dikwels in die praktyk waargencem, toon dit ook dat 'n semenmonster mel abnormale eienskappe (gemeet aan die standaarde van dic Wêreldgesondheidsorganisasie), wel 'n oŏsict kan bevrug.

\section{GEVOLGTREKKING;}

Dic oěnskynlik verlaagde status van dic epididimis in reprodukticwe funksie blyk die motivering vir die gedelaillecrde sludie van epididimale merkers te bevraagteken. Manlike infertiliteit is cgter steeds 'n sicktetoestand wat volgens alle aanduidings besig is om toe te neem. ${ }^{37.38}$ Die etos van geneeskunde verlang ook van artse meer as net dic blote behandeling van simptome op sigwalarde. Vir die ware klinikus (nic 'n blote fasilitecrler nie) wat daarin geïnteresseerd is om die simptome te verantwoord ten einde die oorsaak van 'n sicktetoestand te bepaal, is die epididimis steeds ' $n$ teikenorgaan vir diagnostiese ondersocke en epididimale merkers steeds dic basiese toerusting om die deurganklikheid en funksie van die epididimis te bepaal.

Dic koste verbonde aan die bepaling van epididimale merkers is minimaal in vergelyking met die uitgawes van indringende legnicke soos skrotale eksplorasies. Die presiese rol van die ensiem in die epididimis en in die fertilisasiepolensiaal van sperme behoort verder ondersoek te word, omrede regulering daarvan belangrike implikasies vir kontrasepsie mag inhou.

Dit is nic buite orde om te spekuleer dat die veelbesproke daling in spermtellings maar net ' $n$ voorloper is van ander dalende kriteria wat eers mellerlyd na vore sal kom nie. ${ }^{37.38}$ In hierdie verband is die bepaling van differensiële spermmotiliteit maar sedert 1987 in die handleiding van die WGO opgeneem ${ }^{31}$ en ander sperm lunksietoetse, soos die akrosoomreaksie ${ }^{40}$, zonabindings-essaid en die hamsteroösiet-penetrasietoets ${ }^{42}$ matr relatief nuwe toevoegings tol die arsenaal van diagnostiese hulpmiddels. Dit sal cers oor 'n paar jaar duidelik word of die daling in spermtellings gepaardgaan met dalings in spermkwaliteit, maar dit is seker dat die eliologic van soclanige alnames nie sonder die hulp van betroubare merkers van die aanvullende geslagsorgane bepaal sal kan word nie. Indien dalings in spermkwaliteit die dalings in spermtelling sou vergesel, is dit seker dat die moontlikheid vall aantasting van dic epididimis nic langer geïgnorecr sal kan word nic.

Soos verduidelik, is die daarstel valn 'n spesificke biochemiese milieu (wat verskil oor dic lengle van die epididimis) noodsaaklik vir spermmaturasic in nie-patologiese deurganklike epididimes. Deurganklike epididimes is lank nie meer 'n vereiste vir suksesvolle in vitro-bevrugting nie en in hierdic geval kan epididimale deurganklikheid dus as 'n bysaak beskou word, mits hoëtegnologie noodsalaklik vir direkte sperminspuitingstegnicke heskikbaar is. Wanneer die reprodukticwe gesondheid van 'n bevolking egter as gehecl beskou word, kan die epididimis nooit van die tonecl verdwyn nic. Dit is juis noodsaaklik dat dic hoofrol daarvan in in vivo-bevrugting verder ondersoek en heskerm sal word leen polensieel gevalarlike omgewingsbesoedelingsfaktore.

\section{Summary}

\section{Introduction}

Historically, the epididymis was seen as indispensable for the maturation and storage of sperm, while the absence of patent epididymes precluded suecessful assisted reproduction. Lately, this status of the epididymis has been ehallenged by several issues, seeming to reduce the role of this organ to a merely incidental one. The first issue is the modern-day practice of men to wear relatively tight clothing, which substantially increases the ambient temperature of the scrotum and thus the epididymis, apparently causing a direct decrease in the storage capacity of the epididymis and in the subsequent quality of ejaculates. The second issue is the giant strides recently taken in reproductive lechnology, c.g. live births resulting from epididymal and testicular sperm aspirations and subsequent micro-assisted sperm injection of human oocyles. This review will focus on the role of the epididymis in male fertility and its importance in modern day reproductive research, with special reference to $\alpha$-glucosidase, the epididymal marker of choice.

\section{Anatomy of the epididymis}

The epididymis is a highly convoluted tube of approximately 6 metres in length, connecting the test is with the vas deferens. It is of great importance in the post-testicular development of sperm fertilization potential. Sperm concentrations are low in the test is and increase over the length of the epididymis, as a result of thuid absorption.

\section{The epididymis and maturation of sperm}

When epididymal function is studied, all results must be interpreted taking into account that epididymal function is dependent on sulficient testosterone supplies. Several factors intluence 
the biochemical composition of the intraluminal lluid along the length of the epididymis, including the resorption of water, the secretion and absorption of diluents (both organic and inorganic) by the epididymal epithelium, and the metabolism of specific substances by sperm.

The secretion of diluents by the epididymal epithelium may be directly from the blood stream, as is the case with L-carnitine, or via epithelial synthesis from precursors from the blood, as in the synthesis of proteins from amino acids. The synthesis and secretion of proteins are regionally specific, resulting in the exposure of sperm to an ever-changing, unique environment during progress through the epididymis. Some of these proteins are bound to or incorporated into the sperm membrane. It is generally accepted that changes in the composition of intraluminal epididymal lluid should affect the maturation of sperm negatively, with resultant effects on male fertility.

The existence of the blood-epididymal barrier is essential to maintain the biochemically specialized intraluminal environment. This barrier is composed of tight junctions between the epididymal epithelial cells, preventing free diffusion of larger molecules between the epididymal lumen and the blood circulation. It is the main mechanism for regulating the entrance and exit of substances to and from the lumen, while it protects sperm from toxic metabolites, environmental factors and the body's immune systcm.

Sperm maturation: motility and fertility potential. Sperm maturation involves the development of the capacity for forward progression and for fertilization. In this regard, changes in the metabolism and the sperm membrane are very important. Sperm released from the caput epididymis are immotile or display only broad, slow sweeping movements, in contrast with the rapid movements of mature sperm. The ability of human sperm to bind and penetrate oocytes has been shown to increase during epididymal transit.

Live births resulting from in vitro fertilization with sperm aspirated from obstructed epididymes and even the testis, question the crucial importance of the exposure of sperm to the epididymal environment. These apparent discrepancies were suggested to be caused by "skewing" of the normal pattern and place of sperm maturation in the obstructed epididymis and by the limited assumption of epididymal functions by the vas deferens and the vasa efferentia in cases of obstructed epididymes. Post obstruction changes in the epididymis may also be irreversible, further complicating conclusions from the results of studies of the re-establishment of ductal patency.

\section{The transport and storage of sperm in the epididymis}

The time needed for sperm transport depends on the daily production rate of sperm; a period of only 2 to 4 days may occur in humans. The apparent inability of the human cauda epididymis to preserve sperm function over long periods is partly explained by the elevated environmental temperature of the epididymis, induced by wearing relatively tight clothing and exacerbated by the modern-day sedentary lifestyle, which has a negative influence on epididymal function, particularly those functions pertaining to the preservation of sperm quality.

\section{The epididymis and fertility}

Azoospermia is found in 3 to $18,4 \%$ of all infertile males. The incidence of infertility due to abnormal epididymal function is not known, but epididymal obstruction is the most common cause of obstructive azoospermia (no sperm in the ejaculate due to an obstruction of the epididymis), as opposed to secretory azoospermia (no sperm in the ejaculate due to spermatogenic arrest). Three biochemical components of the seminal plasma, all originating from the epididymis, have been proposed for differentiating between spermatogenic arrest and epididymal obstruction. These include the $\alpha$-glucosidase enzyme, glycerophosphocholine and L-carnitine. The levels of all three are drastically reduced after vasectomy.

\section{$\alpha$-Glucosidase-activity: epididymal marker of choice}

$\alpha$-Glucosidase activity was the marker of choice, classifying $88,4 \%$ of cases correctly as either obstructive or non-obstructive, using the lower limit of $26,7 \mathrm{mU} /$ jaculate. The advent of the EpiScreen (R) $\alpha$-glucosidase kit on the market (FertiPro N.V., Sint-Martens-Latem, Belgium) has made the use of this marker even more altractive, especially for routine diagnostic use. For research purposes, when subtle changes in epididymal function might be expected, the epididymal specilic method is still the method of choice.

For correct interpretation of this epididymal marker, the hormonal profile of the patient or subject in question must be normal, since the epididymis is functionally dependent on adequate supplies of testosterone. When an azoospermic patient is investigated, it must also be accepted that a single parameter, determined in a single sample, can never fully explain the fertility status of such a paticnt.

$\alpha$-Glucosidase activity and sperm motility. $\alpha$-Glucosidase is not found in sperm and its role in the epididymis is to assist in the provision of energy for the development of sperm motility. Though certain studies have failed to prove a relationship between $\alpha$-glucosidase activity and sperm motility, others have indicated statistically significant, though weak, positive correlations between $\alpha$-glucosidase activity and differential sperm motility. This emphasises that sperm motility is influenced by multiple factors and that $\alpha$-glucosidase activity is at least partly a reflection of epididymal function per se.

$\alpha$-Clucosidase activity and fertilization. A relationship between $\alpha$-glucosidase activity and fertilization has been implicated by the positive correlation between $\alpha$-glucosidase activity and the percentage of sperm bound to the zona pellucida of the oocyte, which is the first step in the fertilization process. An attempt was made to determine an in vivo cut-off point for predicting patency of the epididymis, by determining the seminal $\alpha$-glucosidase activity of a group of proven fertile fathers. The range of activity measured was found to be very wide and the fathers presented with values indicative of both patent and obstructed epididymes, according to the previously determined cut-off point of $26.7 \mathrm{mU} /$ ejaculate. This emphasizes that a semen sample with abnormal characteristics according to the definitions of the World Health Organization, can often cause fertilization.

\section{Conclusion}

The apparent erosion of the status of the epididymis in reproductive function seems to undermine the motivation for detailed studies of epididymal markers. Male infertility is, however, a disease which is apparently increasing and not only a hurdle to be overcome when striving to meet the needs of infertile couples. The cthos of medicine also requires more from medical practitioners than merely the treatment of symptoms on their face value. For the true clinician, interested in determining the aetiology of a discase, the epididymis will remain a target organ and epididymal markers will endure as basic, cost-effective tools for determining the patency and function of the epididymis. 
The precise role of the $\alpha$-glucosidase enzyme in the epididymis needs to be further investigated, as regulation thereof might have important implications for contraceptive use. Furthermore, it is not far felched to speculate that the much publicized decrease in sperm count might be accompanied by decreases in sperm function, the actiology of which can only be determined by the use of reliable markers of the accessory reproductive organs. In this regard, it is certain that the epididymis cannot be ignored.

Since patent epididymes are no longer essential for successful in vitro lertilisation, the epididymis might here be considered as a mere side-issue, providing that the sophisticated technology for direct sperm injection is available. When the reproductive health of the population as a whole is considered, however, the epididymis can never be relegated to a mere side-issuc. On the contrary, the leading role of the epididymis should be further investigated and, for the sake of the reproductive future of the nation, the epididymis should be protected from potentially harmlul environmental toxins.

\section{IITERATUURVERWYSINGS}

I. Cooper, T.G. (1986). The epididymis, sperm maturation and ferrilisation (Springer Verlag, Heidelberg).

2. Yamomolo, M.\& Turner, T.T. (1991). Epididymis, sperm maturation and capacitation. In Infertility in the male, 2nd ed., Lipshultz, L.I., Howards, S.S. cds. (Mosby-Ycar Book, St. Louis) pp. 103-111

3. Turner, T.T. (1979). On the epididymis and its function, Imv. Urol, 16, 311-321.

4. Schlegel, P.N. \& Chang, T.S.K. (1992). Physiology of malc reproduction: the testis, epididymis, and ductus deferens. In Campbell's Urology, 6th ed., vol. 1., Walsh, P.C., Retik, A.B., Stamey, T.A. \& Vaughan, E.D. eds. (W.B. Saunders, Philadelphia) pp. 190-220.

5. Bedford, J.M. (1994). The status and the state of the human epididymis, Hum. Reprod. Updale, 9, 2187-2199.

6. Temple-Smith, P.D., Southwick, G.J., Yates, C.A., Trounson, A.D. \& de Kretser, D.M. (1985). Human pregnancy by in vitro fertilization (IVF) using sperm aspirated from the epididymis, $J$. In Vitro Fert. Embryo Trans.s., 2, 119-22.

7. Schoysman, R., Van der Zwalmen, P., Nijs, M., Segal, L., SegalBertin, C., Geerts, L., Van Rosendaal, E. \& Schoysman, D. (1993). Pregnancy after fertilization with human testicular sperm (letter), Lancet, 342, 1237.

8. Von Lanz, T. \& Neuhäuser, G. (1964). Morphometrische analyse des menschlichen nebenhodens, Z. Anat. Entwicklumgsgesch, 124, 126.

9. Flickinger, C.J., Howards, S.S. \& English, H.F. (1978). Ulırastructural differences in efferent ducts and several regions of the epididymis of the hamster, Am. J. Anat., 1,52, 5.57-586.

10. Cornwall, G.A. \& Hann, S.R. (1995). Specialized gene expression in the epididymis, J. Androl., 16, 379-383.

II. Suzuki, F. \& Nagano, T. (1978). Development of tight junctions in caput epididymal epithelium of mouse, Dev Biol., 63, 321.

12. Holstein, A.F. (1969). Morphologische studien am nebenhoden des mensche, Zwanglose Abhaudl. Gebeit. Norm. Pathol. Anat., 20, I.

13. Cooper, T.G., Yeung, C.-H., Nashan, D. \& Nieschlag, E. (1988). Epididymal markers in human infertility, J. Androl., 9, 91-101.

14. Moore, H.D.M. (1990). Development of sperm-egg recognition processes in mammals, J. Reprod. Ferril. Suppl., 42, 71-78.

15. Yeung, C.-H., Cooper, T.G., Oberpenning, F., Schulze, H. \& Nieschlag E. (1993). Changes in movement characteristics of human spermatozoa along the length of the epididymis, Biol. Reprod., 49, 274-280.

16. Schoysman, R., Vanderzwalmen, P., Nijs, M., Segal, L., Segal-Berin, G., Gecrs, L., Van Roosendaal, E. \& Schoysman-Deboeck, A. (1994). Pregnancy oblained with human testicular spermatozoa in an in vitro fertilization program, J. Antrol., 15 Suppl, 10S-13S

17. Silber, S.J. (1989). Role of epididymis in sperm maturation, J. Urol., $33,47-51$
18. Casano, R., Orlando, C., Caldini, A.L., Barni, T., Nalali, A. \& Serio, M. (1987). Simultancous measurement of seminal L-carnitine, alpha-1,4-glucosidase, and glycerylphosphorylcholine in azoospermic and oligozoospermic patients, Fertil. Steril., 47, 324-328.

19. Yanagimachi, R. (1994). Fertilization mechanisms in man and other mammals. In Male fac:or in human inferrility, Tesarik, J. ed. (AresSerono Symposia, Rome) pp. I5-43.

20. Swerdlofi, R.S. \& De Kretser, D.M. (1983). Endocrine evaluation of the infertile male. In Inferfility in the male, Lipshultz, L.I. \& Howards, S.S. eds. (Churchill Livingstone, New York) pp. 211-212.

2I. Herlihy, R., Lee, R.D. \& Lipshultz, L.I. (1987). Evaluation of the infertile male. In Andrology, Pryor, J.P. \& Lipshultz, L.I. eds. (Bulterworths, London) pp. 242-260.

22. Baker, H.W.G., Burger, H.G., De Kretser, D.M. \& Hudson, B. (1986). Relative incidence of etiological disorders in male infertility. In Male reproductive dysfinction. Santen, R.J. \& Swerdloff, R.S. eds. (Marcel Dekker Inc., New York) pp. 341-372.

23. Van ZyI, J.A., Menkveld, R., Retief, A.E. \& Van Niekerk, W.A. (1976). Oligozoospermia. In Human semen and fertility regulation in men, Hafez, E.S.E. ed. (The CV Mosby Company, Saint Louis) pp. 363-369.

24. Lipshultz, L.I. \& Howards, S.S. (1983). Evaluation of the subfertile man. In Infertility in the male. Lipshultz, L.I. \& Howards, S.S. eds. (Churchill Livingstone, New York) pp. 195-201

25. Fouric, M.H., Bornman, M.S., Wolmarans, L., Reinach, S.G. \& Du Plessis, D.J. (1992). Alfa-glukosidase as cpididmale merker in obstruktiewe asoöspermic, Geneeskunde, 34, 8-1,3.

26. Cooper, T.G., Yeung, C.-H., Nashan, D., Jockenhövel, F. \& Nieschlag, E. (1990). Improvement in the assessment of human epididymal function by the use of inhibitors in the assay of $\alpha$-glucosidase in seminal plasma, Int. J. Androl., 13, 297-30.5.

27. Fouric, M.H. \& Bornman. M.S. (1994). Epididymal markers in azoospermia, Afr. J. Urol. 1, 43-48.

28. Amelar, R.D., Dubin, L. \& Schoenfeld, C.Y. (1980). Sperm Motilily, Feritl. Steril., 34, 197-21.5.

29. Chapdelaine, P., Tremblay, R.R., Dube, J.Y., St-Yves, C. \& Mailhot. J. (1978). Origin of maltase and variations in infertile men, Arch. Androl., 1, 61-68.

30. Yeung, C.H. \& Cooper, T.G. (1994). Siudy on the role of epididymal $\alpha$-glucosidase in the fertility of male rats by the administration of the enzyme inhibitor castanospermine, J. Reprod. Fert., 102, 401410.

31. Purvis, K., Brekke, I. \& Tollefsrud, A. (1991). Epididymal secretory function in men with asthenozoospermia, Humum Reprod., 6. $8.50-8.53$

32. Guerin, J.-F., Ali, H.B., Coltinet, D. \& Rollet, J. (1990). Seminal $\alpha$ glucosidase activity as a marker of epididymal pathology in nonazoospermic men consulting for infertility, J. Androl. II, 24024.5 .

33. Tremblay, R.R., Chapdelaine, P. \& Mailhot, J. (1979), $\alpha$-I,4-Glucosidase activity in human semen: variations with number and motility of spermatozoa, Fertil. Steril., 31, 592-593.

34. Fouric, M.H. (1995). Epididymal markers with specific reference 1o $\alpha$-glacosidase in infertile males. M.Sc. Thesis, University of Pretoria, Pretoria.

35. Combaire, F. \& Vermeulen, L. (1995). Human semen analysis, Hum. Reprod. Updale. 1, 34,3-362.

36. Cooper, T.G., Weidner, W. \& Nieschlag, E. (1990). The influence of inflammation of the human male genital tract on secretion of the seminal markers $\alpha$-glucosidase, glycerophosphocholine, carnitine. fructose and citric acid, Int. J. Androl.. 13, 329-336.

37. Ben Ali, H., Guerin, J.F., Pinatel, M.C., Mathieu, C., Boulieu, D. \& Tritar B. (1994). Relationship between semen characteristics, $\alpha$ glucosidase and the capacity of spermatozoa to bind to the human zona pellucida, III. J. Androl., 17, 121-126

38. Van Waeleghem, K., De Clerq, N., Vermeulen, L., Schoonjans, F. \& Comhaire, F. (1994). Deterioration of sperm quality in young Belgian men during recent decades, $H u m$. Reprod., 9, Supplement 4.73.

39. Irvine, S., Cawood. E., Richardson, D., Macl Donald E., Aitken, J. (1996). Evidence of deteriorating semen quality in the United King- 
dom: birth cohor study in 577 men in Seotland over 11 years, BMJ., $312,467-471$

40. World Health Organization. (1987). WHO Laboratory mamal for the examination of human semen and sperm-cervical machs interaction. 2nd ed. (The Press Syndicate of the University of Cambridge, Cambridge).

41. Cross, N.L., Morales, P., Overstreet, J.W. \& Hanson, F.W. (1986). Two simple methods for detecting acrosome-reacted human sperm. Gamete Res., 15, 213-226.

42. Burkman, L.J., Coddington, C.C., Franken, D.R., Kruger, T.F.,
Rosenwaks, Z. \& Itodgen, G.D. (1988). The hemizona assay (HZA): Development of a diagnostic test for the binding of human spermatozoa to the human zona pellucida to predict fertilization potential. Fertil. Steril., 49, 688-697.

43. Aitken, R.J., Templeton, A., Schats, R.. Best, F., Richardson, D., Djahanbakhch. O. \& Lees, M. (1983). Methods of assessing the functional capacity of human spermatozoa: their role in the selection of patients for in vitro fertilization. In Ferrilization of $\mathrm{the} H \mathrm{H}$ nan Egg in vitro. Beier. H. \& Lindner, H. eds. (Springer-Verlag, Berlin) pp. 147-165. 